\title{
Comprehensive Study of the Physical and Chemical Properties of Phosphorus Sludge and Cottrell Dust
}

\author{
Ulzhalgas Nazarbek', Uilesbek Besterekov¹, Perizat Abdurazova1, Saule Nazarbekova1, \\ Yerkebulan Raiymbekov ${ }^{1 *}$

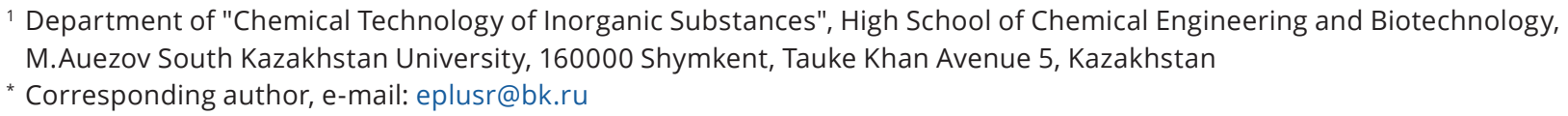

Received: 24 February 2021, Accepted: 07 May 2021, Published online: 24 August 2021

\begin{abstract}
The article presents the results of physico-chemical research of waste from the phosphorus industry - phosphorus sludge and cottrell dust. The reliability of the experimental results was ensured by the use of generally recognized research methods, as well as reliable physico-chemical and instrumental methods of analysis. The results of the experiment prove the suitability of these types of waste for the production of mineral fertilizers. This, in turn, will make it possible to improve the environmental situation in the southern region of Kazakhstan.
\end{abstract}

\section{Keywords}

phosphorous sludge, cottrell dust, phosphorus-containing waste, mineral fertilizers

\section{Introduction}

The development of the industry around the world has made the problem of complex processing of technogenic waste and attracting substandard mineral resources to production urgent. An example is the production of phosphorus, which is widely in demand both in Kazakhstan and abroad. Its production is due to the formation of large technogenic waste in the form of slag, ferrophosphorus, phosphorus sludge and cottrell dust. Only in the Zhambyl region, more than 30 million tons of these wastes have been accumulated $[1,2]$.

According to the Statistics Committee [3], the country has accumulated more than 30 billion tons of technogenic waste, a significant part of which is toxic. Now technogenic waste should be considered as an independent raw material base. Today, as a result of the reduction of electric smelting of phosphorite raw materials at the NovoDzhambul phosphorus plant alone, about 140-160 kg of cottrell dust is formed per 1 ton of production yellow phosphorus, which is discharged into evaporation basins in the form of a suspension - cottrell milk [4]. In addition, on the territory of the former phosphorus plant in Shymkent has accumulated more than 500 thousand tons of phosphorous sludge, which in its chemical and granulometric composition is characterized by complex inclusions of mineral components of the charge and processed products $[5,6]$.
Research by scientists and manufacturers, as well as laboratory experiments show that these technogenic wastes are quite valuable secondary raw materials for the production of composite building materials. The authors used phosphorous sludge of Kazphosphate Limited Liability Partnership (LLP), ferrochrome slag of the Aktobe ferrochrome plant of Transnational Company (TNK) "Kazchrome" and shell rock of the Mangystau region. Compounded bitumen based on tar and BND 60/90 (Bitum Neftjanoj Dorozhnyj - Oil Road Bitumen), processed by us by the method of microwave radiation, was used as a binding material. As a result of experimental work, the optimal composition of two types of asphalt concrete was found: fine-grained and crushed-mastic asphalt concrete $[7,8]$. The authors claim that there is a wide possibility of using such asphalt-concrete mixtures for the use of both the lower and upper layers of the bases for road surfaces. The resulting asphalt concretes are not inferior to expensive analogues both in price and quality.

There are known methods and technologies for the extraction of phosphorus [9-16], production of phosphorous and complex phosphorus-potassium-containing mixed fertilizers, potassium ammo-phosogypsum meliorant, superphosphate, double superphosphate, urea-ammonia fertilizer, 
monoammonium phosphate (MAF), and ammophos based on phosphorus-containing technogenic waste [17-19]. Production modes were worked out and the main characteristics of the final product were determined.

Thus, to date, there are no fully justified technologies for processing phosphorus-containing waste into marketable phosphorus-, nitrogen-, and potassium-containing products. The problem of integrated waste management is not solved. The proposed technologies are imperfect, which explains the presence of a non-decreasing volume of waste. Therefore, the known technological solutions have not found a full-scale practical application. In this regard, the search for new opportunities for the utilization of multi-tonnage phosphorus-containing secondary raw materials is still relevant.

Taking into account the above, the scientific novelty of this research work is to conduct a comprehensive study of the structure and composition of phosphorus-containing waste for further use as a raw material in the production of mineral fertilizers and other chemical industries.

\section{Materials and methods}

The objects of the study were phosphorus sludge from the sludge storage facility of Kainar LLP (former phosphorus plant in Shymkent, South Kazakhstan) and cottrell dust from the dumps of Kazphosphate LLP (Taraz). In appearance, the samples are grayish-black in color and finely divided.

To solve the tasks of the research work, experimental, physico-chemical and analytical methods of research were used: sieve analysis, IR spectroscopic analysis, analysis on the X-ray energy-dispersive microanalyzer INCAEnergy (Oxford INSTRUMENTS), mounted on a scanning electron microscope ISM-6490LV (IED).

For the separation and sorting of raw materials by particle size, sieving was performed on a vibrating screen screen "Analizette 3". The dry sieving ranges are from 100 microns to $24 \mathrm{~mm}$.

Microstructural and elemental-weight studies were performed with the use of modern equipment of the SEM (scanning electron microscope JEO1, brand JSM6490 LV). During the study, a special, double-sided adhesive tape with a length of $6 \mathrm{~mm}$ is applied to the samples. Blow the table with the test material with a jet of clean air and install it in the working chamber of the microscope. Then the electron microscope is pumped out to a high vacuum, checking the operation of the vacuum system nodes. After that, an image of the object under study in secondary electrons is obtained by selecting a pre-accelerating voltage of $20 \mathrm{kV}$, the diameter of the electron probe of $40 \mathrm{~nm}$, and the inclination of the eucentric table of 0 degrees. [20].

IR spectral analysis of phosphorus sludge and cottrell dust was carried out on the apparatus FT-IR spectrometer Shimadzu IR Prestige-21 with the prefix frustrated total internal reflection (FTIR) Miracle firms PikeTechnologies. To obtain the spectra of the original samples, the spectrum is recorded in the transmitted IR radiation, having previously fixed the samples in a special holder. It is a plate with a rectangular hole, to which the sample is pressed, covered on top with a magnetic plate with a hole in the center [21]. The data obtained was decoded using the LabSolutions IR software.

$\mathrm{X}$-ray phase analysis was performed on the DRON-3 device, and the radiographs were decoded using the ASTM card file and the Mikheev X-ray detector [22]. The samples were prepared by pressing into tablets of the same density without the use of an additional binding component.

\section{Results and discussion}

A representative sample of phosphorous sludge from Kainar LLP was obtained for the research. Fig. 1 shows the results of the sieve analysis of the phosphorus sludge under study.

From the data of Fig. 1, it follows that about $1 / 3$ of the phosphorus sludge is accounted for by a small fraction with particle sizes of $0.100-0.315 \mathrm{~mm}$, about $5 \%$ are large fractions with sizes of more than $1.4 \mathrm{~mm}$. The share of dust-like particles is about $18 \%$. The bulk of the phosphorus sludge is made up of fractions with sizes: $1.0-1.4 \mathrm{~mm}$; 0.71-1.0 mm; $0.50-0.71 \mathrm{~mm} ; 0.315-0.500 \mathrm{~mm}$, the mass fraction of these fractions is approximately the same and averages $13 \%$.

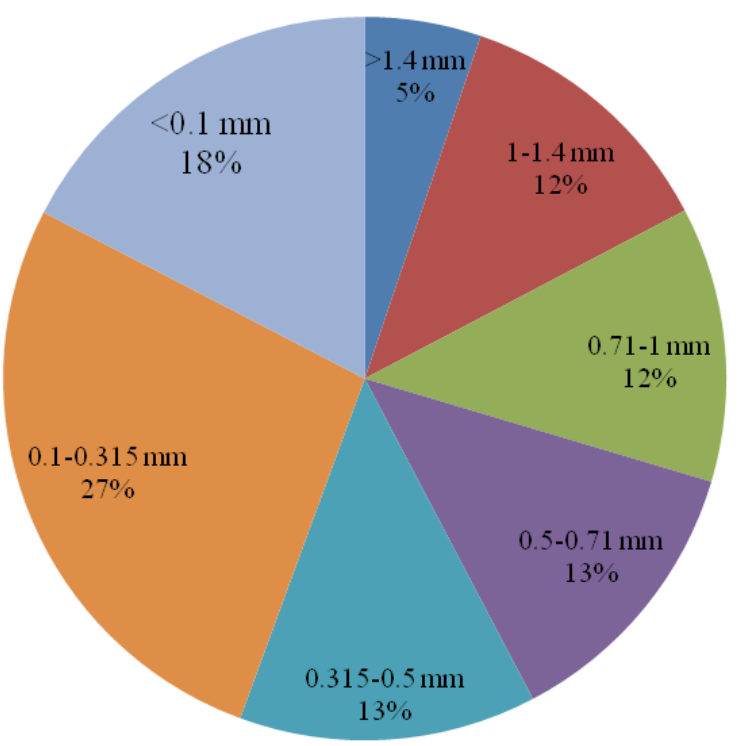

Fig. 1 Results of the sieve analysis of phosphorous sludge sample from Kainar LLP 
Fig. 2 shows the results of the sieve analysis of the investigated cottrell dust of "NDFZ" Kazphosphate LLP.

From the data in Fig. 2, it follows that about 1/3 of the cottrell dust is accounted for by a small fraction with particle sizes of $0.100-0.315 \mathrm{~mm}$, about $14 \%$ are large fractions with sizes of more than $7.1 \mathrm{~mm}$. The share of pulverized particles of cottrell dust is approximately $4 \%$.

The main mass of cottrell dust is made up of fractions with dimensions: $7.1-5.0 \mathrm{~mm} ; 3.15-2.00 \mathrm{~mm} ; 2.0-1.4 \mathrm{~mm}$; $1.4-1.0 \mathrm{~mm} ; 1.0-0.71 \mathrm{~mm} ; 0.710-0.500 \mathrm{~mm}$; the mass fraction of these fractions is approximately the same and in the total mass is about $50 \%$.

The microstructure observed at a 40 -fold magnification of the studied sample of the sludge sample is shown in Fig. 3.

From the data in Fig. 3, it follows that the total composition of the analyzed sample is characterized by the presence of inclusions of large particles of calcium silicate minerals in the form of irregularly shaped fragmentary hexagonal crystals of $2 \mathrm{CaO} \cdot \mathrm{SiO}_{2}$ and rounded small grains of $\mathrm{CaO} \cdot \mathrm{SiO}_{2}$ vollostonite.

The structure of the analyzed surface contains: single oval-shaped minerals $\mathrm{CaO} \cdot \mathrm{Al}_{2} \mathrm{O}_{3}$; compounds of potassium aluminosilicates, which are small inclusions of colorless isometric tabular mineral structures with grain sizes of 6-10 microns. Transparent gray film-like and border-like formations are characteristic of minerals: calcium phosphate $3 \mathrm{CaO} \cdot \mathrm{P}_{2} \mathrm{O}_{5}$ and calcium fluoride $\mathrm{CaF}_{2}[20]$.

As follows from Fig. 3, the studied surface of cottrell dust is characterized by imperfect soldering of minerals with the formation of cracks and chips. The main mineralogical

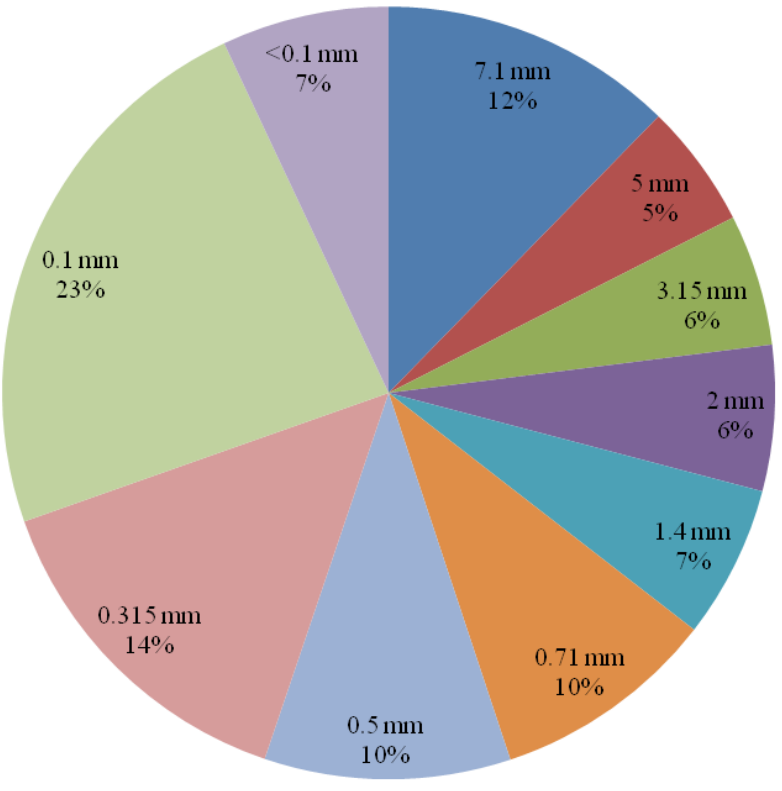

Fig. 2 Results of the sieve analysis of cottrell dust from Kazphosphate LLP

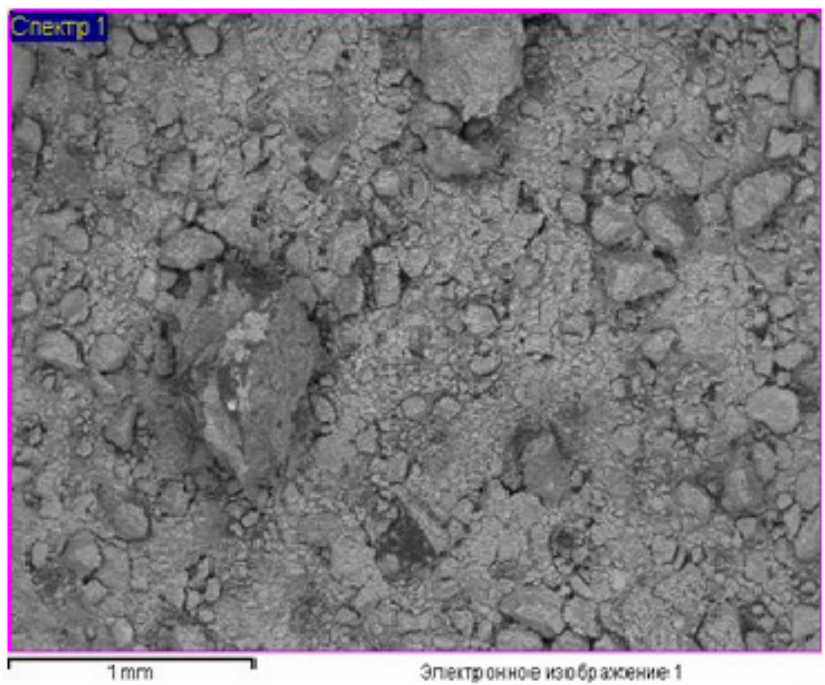

(a)

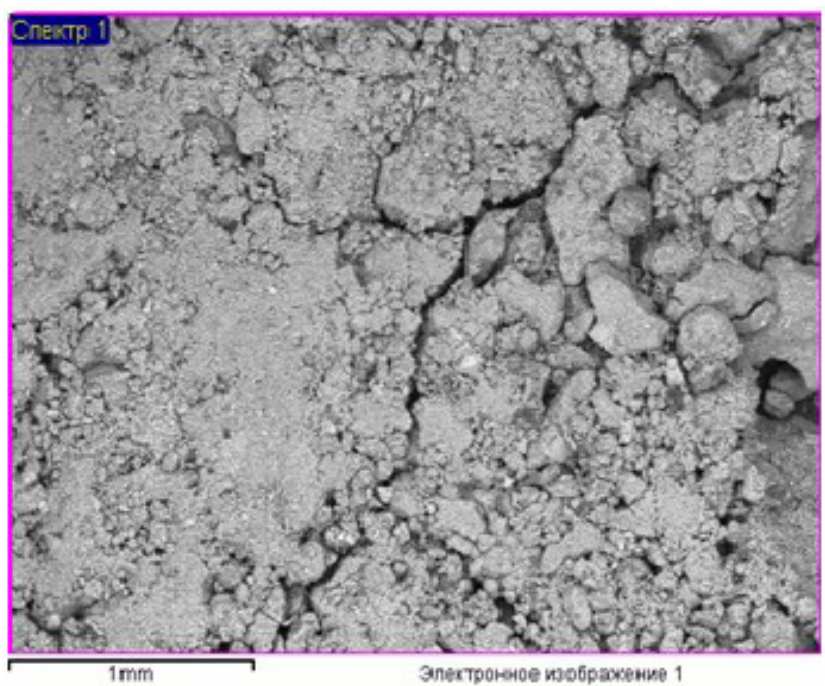

(b)

Fig. 3 Microstructure of phosphorous sludge and cottrell dust obtained at 40-fold magnification; (a) Phosphorous sludge; (b) Cottrell dust

phases of the sample are silicophosphates and silicofluorophosphates, which have colorless plate-like crystal structures. Intermediate crystals of calcium phosphates are characterized by bluish short irregular prisms. Small inclusions of potassium phosphates are characterized by soldered crystals of small elongated plates of irregular shape.

The accumulation of fine-grained chain structures of calcium silicate crystals is observed around the phosphate minerals. The intermediate spaces and cracks are filled with the carbon phase [17].

IR spectral analysis of phosphorous sludge and cottrell dust was carried out on the device of the Shimadzu IR Prestige-21 Fourier-IR spectrometer with the prefix of the 
disturbed total internal reflection detecting parity violation Miracle of PikeTechnologies.

The results of the IR spectral analysis of phosphorus sludge are shown in Fig. 4. Table 1 show the main peaks based on the results of the IR spectral analysis of phosphorus sludge.

According to the data in Fig. 4 and Table 1, the wavenumbers of 952-906 $\mathrm{cm}^{-1}$ are characteristic of P-F and phosphates, and in the range of $1020-1090 \mathrm{~cm}^{-1}$ indicate the presence of silicate compounds [21].

Table 2 and Fig. 5 show the main peaks based on the results of IR spectral analysis of cottrell dust.

From Fig.e 5 and the data in Table 2, it follows:

- 1049-1060 $\mathrm{cm}^{-1}$ absorption spectra with wavelengths are characteristic of phosphorus compounds $\mathrm{P}=\mathrm{O}$ (with hydrogen bonding);

- 952-906 $\mathrm{cm}^{-1}$ characteristic of P-F and phosphates;

- absorption spectra with wavelengths of 1020$1090 \mathrm{~cm}^{-1}$ characterize the presence of silicate compounds with $\mathrm{Si}-\mathrm{O}-\mathrm{Si}$ valence bonds in cottrell dust;

- absorption spectra in the region of $800-802 \mathrm{~cm}^{-1}$ are characteristic of silicate compounds of charge materials in the valence state of $\mathrm{Si}-\mathrm{O}-\mathrm{Ca}$ and $\mathrm{Si}-\mathrm{O}-\mathrm{Al}$;
Less intense absorption spectra of $1454-1399 \mathrm{~cm}^{-1}$ are typical for phosphorus and free $\mathrm{P}=\mathrm{O}$ compounds.

Fig. 6 shows the X-ray phase analysis of phosphorous sludge. As follows from the data in Fig. 6, the heat-treated phosphorus sludge is characterized by an amorphous phase state and this is confirmed by the low intensity of the differential maxima of its phase components.

The presence of calcium monosilicates is characterized by diffraction maxima with $d=2.553 ; 2.334 ; 1.75 \AA$. The aluminosilicate phases of $2 \mathrm{CaO} \cdot \mathrm{Al}_{2} \mathrm{O}_{3} \cdot \mathrm{SiO}_{2}$ are characterized by similar maxima with $d=3.42 ; 2.72 ; 2.53 \AA$. The phosphorus-containing phases of $2 \mathrm{CaO} \cdot \mathrm{P}_{2} \mathrm{O}_{5}$ - with $d=3.00 ; 3.22 ; 3.07 \AA$. There are also minor peaks characteristic of $\mathrm{CaO} \cdot \mathrm{MgO} \cdot \mathrm{SiO}_{2}$ with $d=4.19 ; 3.67 ; 2.93 \AA$.

Fig. 7 shows the results of X-ray phase analysis of cottrell dust.

Fig. 7 shows that cottrell dust is characterized by an amorphous structure. This is quite convincingly evidenced by the very low intensity of the diffraction maxima of its phase components.

In the composition of cottrell dust, the phosphorus-containing components of charge materials are characterized by the following compounds:

Table 1 The main peaks based on the results of IR-spectral analysis of phosphorus sludge

\begin{tabular}{lcccccc}
\hline Peak $\left(\mathrm{cm}^{-1}\right)$ & Intensity & Corr. Intensity & Base $(\mathrm{H})$ & Base $(\mathrm{L})$ & Area & Corr. Area \\
\hline 551.64 & 70.397 & 1.450 & 567.07 & 547.78 & 2.895 & 0.183 \\
594.08 & 71.895 & 3.159 & 601.79 & 582.50 & 2.628 & 0.171 \\
798.53 & 72.926 & 6.141 & 844.82 & 675.09 & 18.336 & 1.924 \\
910.40 & 69.549 & 0.622 & 914.26 & 848.68 & 8.734 & 0.156 \\
1037.70 & 43.498 & 33.231 & 1330.88 & 956.69 & 58.967 & 29.642 \\
\hline
\end{tabular}

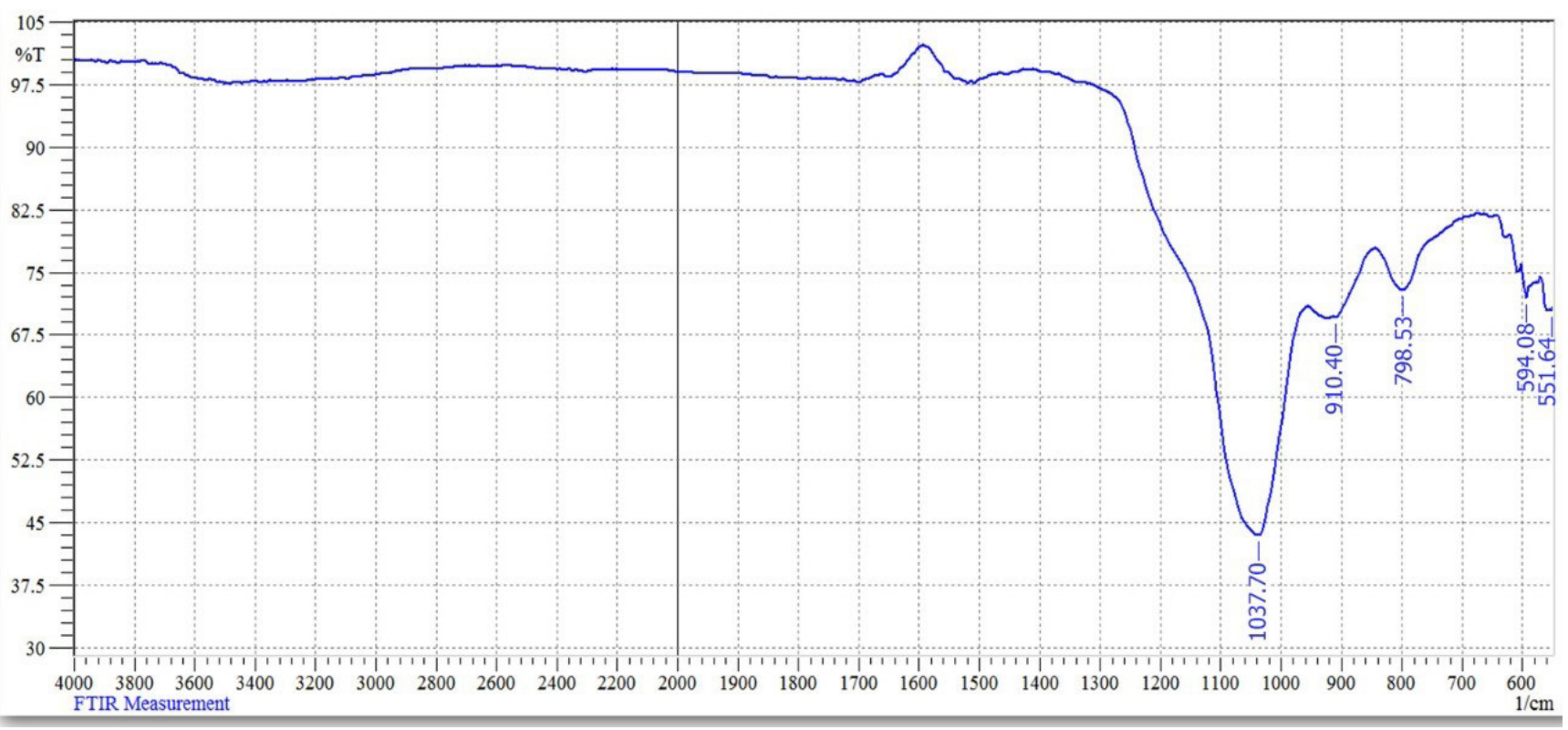

Fig. 4 IR spectral analysis of phosphorous sludge 
Table 2 The main peaks based on the results of IR-spectral analysis of cottrell dust

\begin{tabular}{|c|c|c|c|c|c|c|}
\hline Peak cm ${ }^{-1}$ & Intensity & Corr. Intensity & Base $(\mathrm{H})$ & Base (L) & Area & Corr. Area \\
\hline 802.39 & 55.531 & 2.873 & 837.11 & 698.23 & 32.552 & 1.483 \\
\hline 906.54 & 53.253 & 1.879 & 929.69 & 40.96 & 23.297 & 0.730 \\
\hline 952.84 & 53.666 & 1.542 & 975.98 & 933.55 & 11.214 & 0.265 \\
\hline 1049.28 & 45.046 & 16.969 & 1330.88 & 979.84 & 68.973 & 14.459 \\
\hline 1396.46 & 86.841 & 0.117 & 1404.18 & 1384.89 & 1.174 & 0.005 \\
\hline 1454.33 & 86.599 & 0.269 & 1462.04 & 1442.75 & 1.190 & 0.011 \\
\hline 1635.64 & 86.070 & 0.169 & 1639.49 & 1597.06 & 2.721 & 0.025 \\
\hline
\end{tabular}

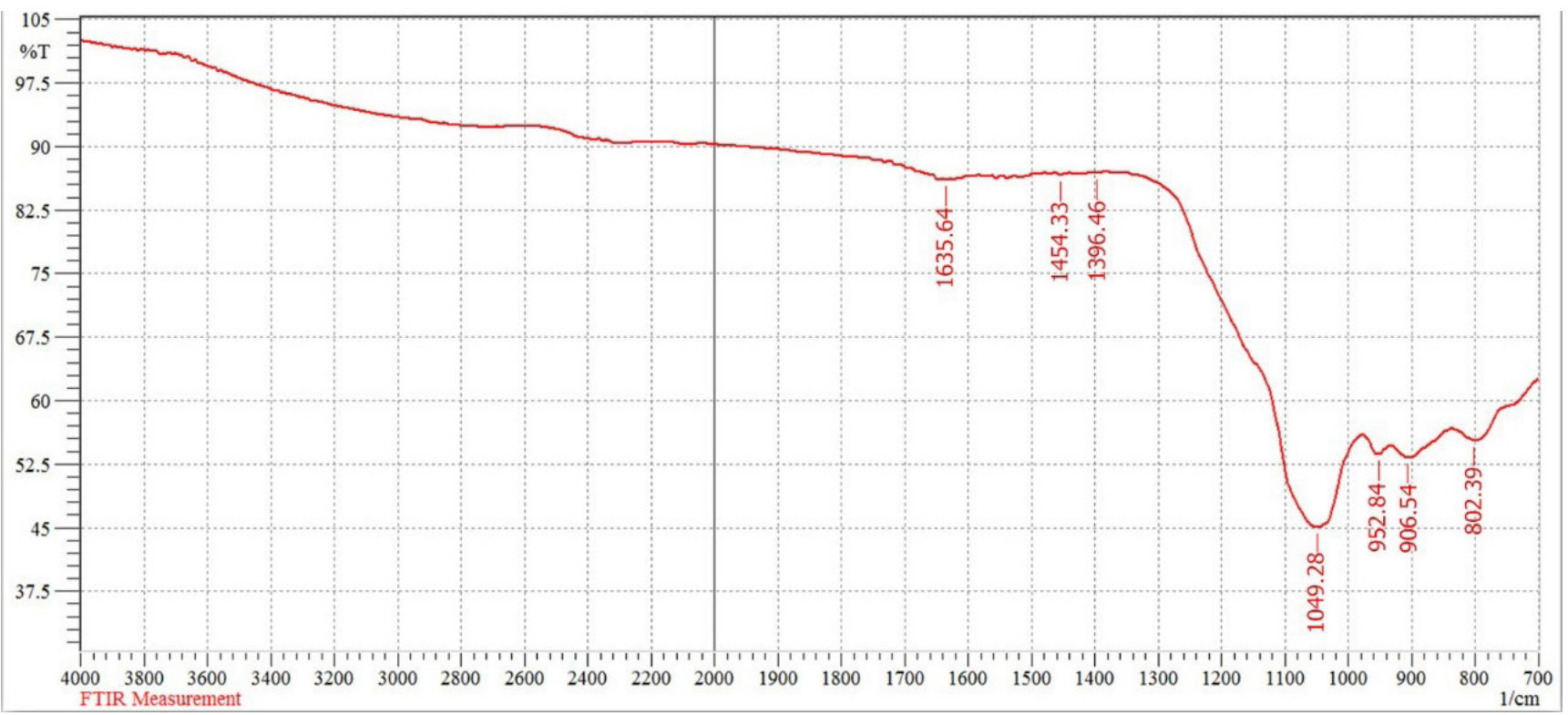

Fig. 5 IR spectral analysis of cottrell dust

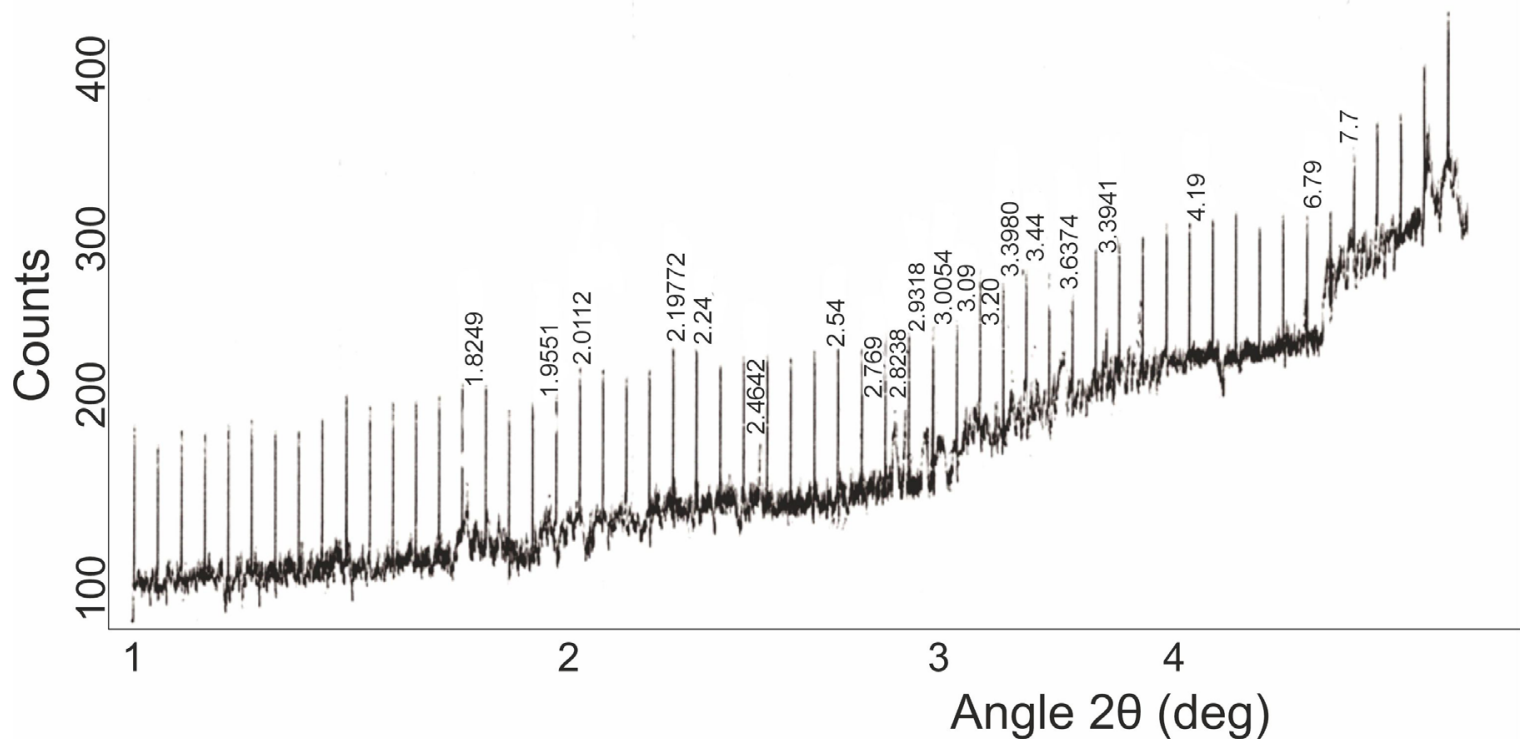

Fig. 6 X-ray diagram of phosphorous sludge

- $3 \mathrm{CaO} \cdot \mathrm{P}_{2} \mathrm{O}_{5}$ with $d=3.22 ; 3.07 ; 3.00 \AA$;

- $\mathrm{Ca}_{5}\left(\mathrm{PO}_{4}\right)_{3} \mathrm{~F}$ with $d=3.06 ; 2.76 \AA$;
There are also compounds of the type $\mathrm{CaHPO}_{4} \cdot 3.5 \mathrm{H}_{2} \mathrm{O}$ with $d=2.24 ; 1.96 \AA$; and $\mathrm{Ca}_{14}\left[\mathrm{PO}_{4} \cdot \mathrm{SiO}_{4} \cdot \mathrm{SO}_{4}\right] \mathrm{Cl}_{2}(\mathrm{OH})_{2} \mathrm{O}$ with $d=1.95 ; 2.795 ; 2.83 \AA$. 


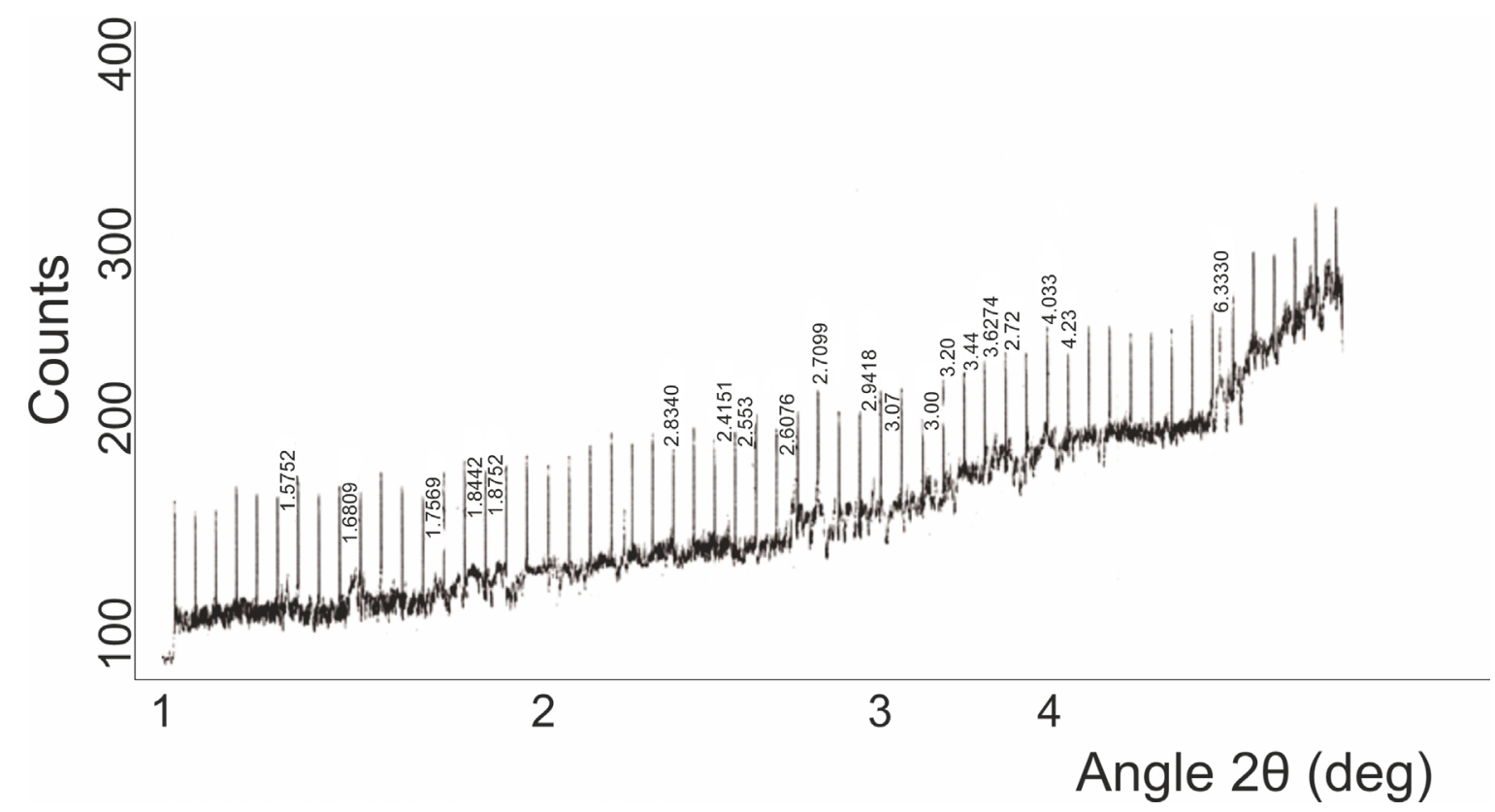

Fig. 7 X-ray diagram of cottrell dust

The main amorphous phases of cottrell dust are calcium silicate compounds $\mathrm{CaO} \cdot \mathrm{SiO}_{2}$ with $d=7.7 ; 3.09 ; 2.01 \AA$ and calcium aluminosilicates $2 \mathrm{CaO} \cdot \mathrm{Al}_{2} \mathrm{O}_{3} \cdot \mathrm{SiO}_{2}$ with $d=3.44 ; 2.53 ; 2.19 \AA[22]$.

The generalized data on the chemical composition of phosphorus sludge and cottrell dust obtained on the basis of processing the results of SEM, XRD, and IR analyses are given in Figs. 8 and 9.

The data from Figs. 8 and 9 clearly demonstrate the presence of basic and impurity compounds in the composition of the samples under study. The content of the main component-phosphorus pentoxide in the composition of cottrell dust is an order of magnitude higher than that of phosphorus sludge. The presence of impurity compounds such as $\mathrm{MnO}, \mathrm{ZnO}, \mathrm{Na}_{2} \mathrm{O}, \mathrm{Fe}_{2} \mathrm{O}_{3}, \mathrm{CaS}_{2}, \mathrm{Al}_{2} \mathrm{O}_{3}$ in both samples indicates the fertilizing value of these types of phosphorus production waste. These types of waste can be used for the production of NPK and PK fertilizers, since the composition has a sufficiently high content of $\mathrm{K}_{2} \mathrm{O}$. Similar studies provide data on the structural and chemical composition

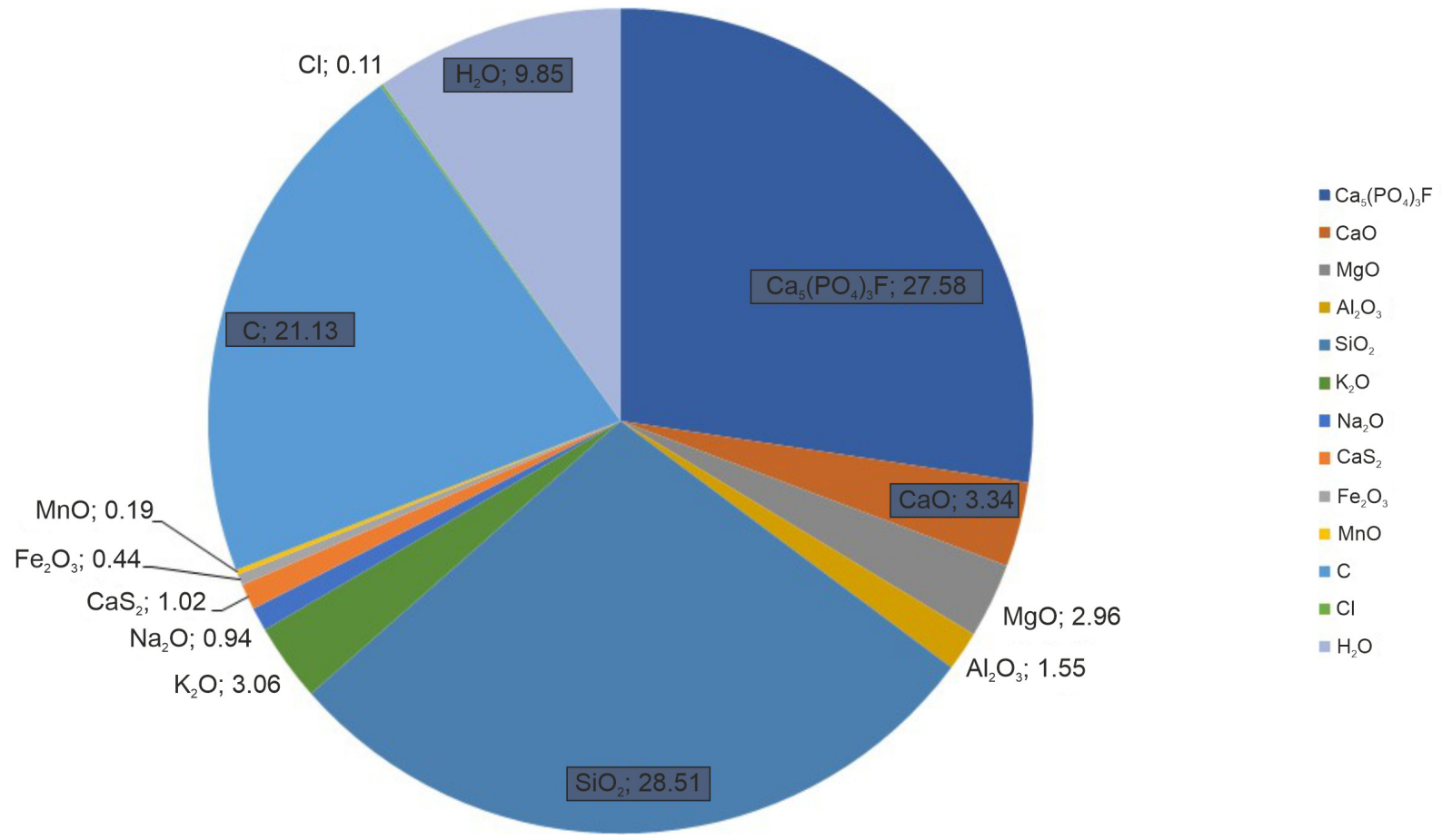

Fig. 8 Chemical composition of phosphorus sludge from Kainar LLP 


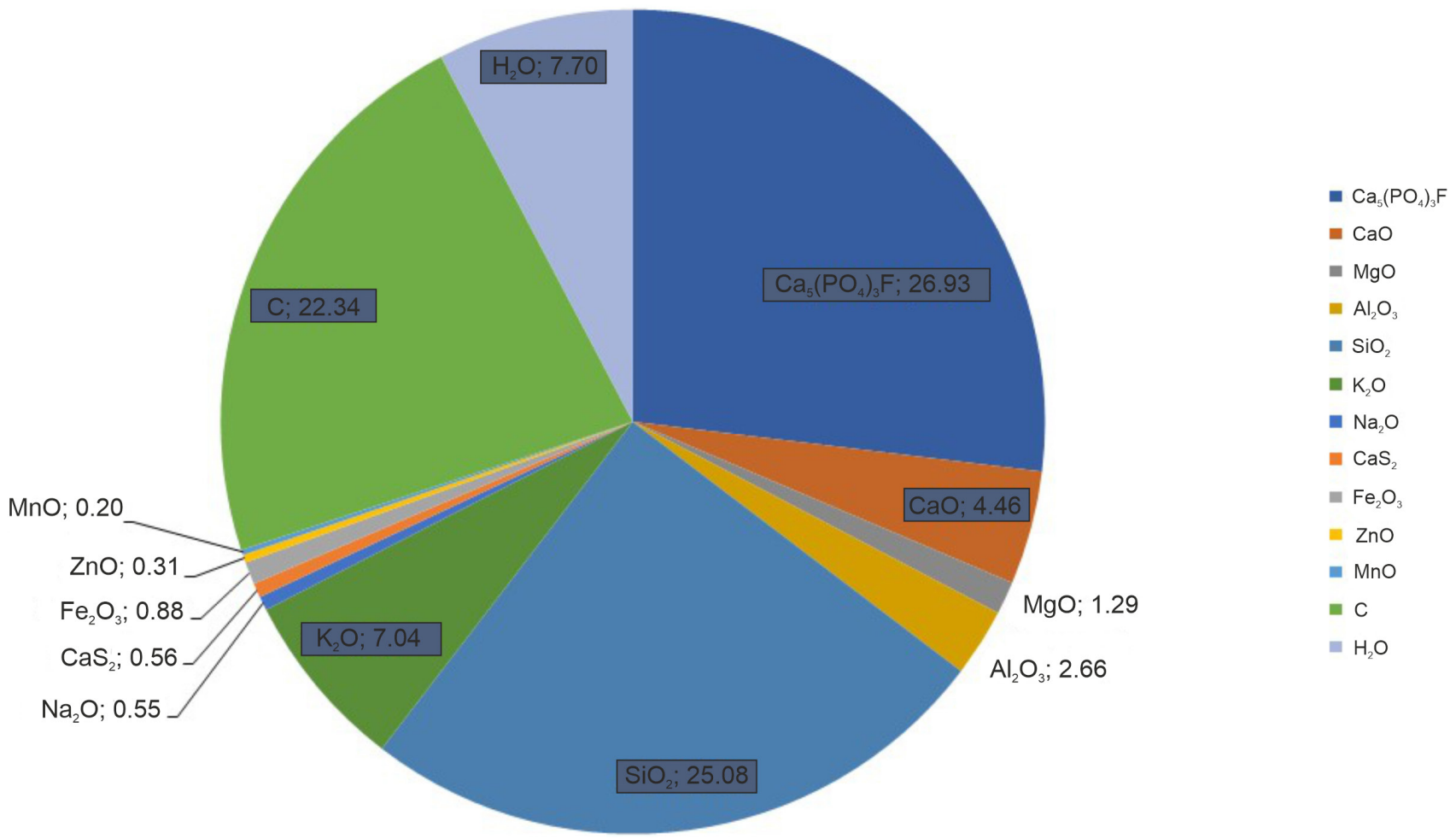

Fig. 9 Chemical composition of cottrell dust from Kazphosphate LLP

of phosphorus sludge. The results of these studies indicate the presence of radioactive elements in the samples. However, the content of these substances is within the maximum permissible limits [23].

\section{Conclusion}

The results of the conducted research allow us to conclude that phosphorus sludge and cottrell dust are valuable secondary phosphate raw materials, which are quite suitable for processing them into phosphorus, potassium-containing complex mineral fertilizer. Moreover, as follows from the analysis of X-ray diagram, phosphorus sludge and cottrell dust have an amorphous structure. This fact

\section{References}

[1] Socheeva, V.E. "Жизненные циклы первичных и вторичных источников фосфора" (Life cycles of primary and secondary sources of phosphorus), International Journal of Humanities and Natural Sciences, 12(1), pp. 25-27, 2018. (in Russian) https://doi.org/10.24411/2500-1000-2018-10320

[2] KazInform International News Agency "Отходы химпроизводства с советского прошлого перерабатывает предприятие в Таразе" (Waste from chemical production from the Soviet past is processed by the enterprise in Taraz), [online] Available at: https://lenta.inform. kz/ru/othody-himproizvodstva-s-sovetskogo-proshlogo-pererabatyvaet-predpriyatie-v-taraze_a3081652 [Accessed: 01 March 2021] (in Russian) quite reasonably allows us to draw an important conclusion of practical significance that for the acid decomposition of their mixture there is no need to use strong and quite expensive mineral acids- $\mathrm{H}_{3} \mathrm{PO}_{4}, \mathrm{H}_{2} \mathrm{SO}_{4}, \mathrm{HNO}_{3}$, etc. a mixture of phosphorous sludge and cottrell dust can be decomposed with a weak acid such as organic acids to produce organomineral fertilizers.

\section{Acknowledgement}

This research is funded by the Science Committee of the Ministry of Education and Science of the Republic of Kazakhstan (Grant No. AP09057884).

[3] Republic of Kazakhstan "National report on the state of the environment and on the use of natural resources for 2018", Ministry of Ecology, Geology and Natural Resources of the Republic of Kazakhstan, Astana, Republic of Kazakhstan, 2018.

[4] Melnik, L. "Возможна ли жизнь современного человека без химии?" (Is it possible for a modern person to live without chemistry?), Kursiv.kz, [online] 06 October 2020. Available at: https:// kursiv.kz/news/kompanii/2020-10/vozmozhna-li-zhizn-sovremennogo-cheloveka-bez-khimii [Accessed: 01 March 2021] (in Russian) 
[5] Nugman, A. S. "В Шымкенте откроют завод по производству минеральных удобрени" (A plant for the production of mineral fertilizers swill be opened in Shymkent), Matritca News Portal [online] 26 November 2016. Available at: http://www.matritca.kz/ news/39705-v-shymkente-otkroyut-zavod-po-proizvodstvu-mineralnyh-udobreniy.html [Accessed: 01 March 2021] (in Russian)

[6] Arystanova, S.D. "Razrabotka tehnologii poluchenija sorbentov iz prirodnogo mineral'nogo syr'ja dlja ochistki fosforsoderzhashhih shlamov" (Development of technology for obtaining sorbents from natural mineral raw materials for the purification of phosphorus sludge), PhD thesis, M.Auezov South Kazakhstan State University, 2018. (in Russian)

[7] Hakkou, R., Benzaazoua, M., Bussière, B. "Valorization of Phosphate Waste Rocks and Sludge from the Moroccan Phosphate Mines: Challenges and Perspectives", Procedia Engineering, 138, pp. 110-118, 2016.

https://doi.org/10.1016/j.proeng.2016.02.068

[8] Ergozhin, E. E., Bektenov, N. A., Sadykov, K. A., Kalmuratova, K. M., Ryspaeva, S. B. "Bituminous concretes on basis of industrial wastes", Chemistry Journal of Kazakhstan, 4(60), pp. 16-20, 2017.

[9] Daneshgar, S., Callegari, A., Capodaglio, A.G., Vaccari, D. "The Potential Phosphorus Crisis: Resource Conservation and Possible Escape Technologies: A Review", Resources, 7(2), Article number: 37, 2018. https://doi.org/10.3390/resources7020037

[10] Jupp, A.R., Beijer, S., Narain, G.C., Schipper, W., Slootweg, J. C. "Phosphorus recovery and recycling - closing the loop", Chemical Society Reviews, 50(1), pp. 87-101, 2021. https://doi.org/10.1039/D0CS01150A

[11] Li, Y., Nan, X., Li, D., Wang, L., Xu, R., Li, Q. "Advances in the treatment of phosphorus-containing wastewater", IOP Conference Series: Earth and Environmental Science, 647, Article number: 012163, 2021. https://doi.org/10.1088/1755-1315/647/1/012163

[12] Cieślik, B., Konieczka, P. "A review of phosphorus recovery methods at various steps of wastewater treatment and sewage sludge management. The concept of "no solid waste generation" and analytical methods", Journal of Cleaner Production, 142(4), pp. 1728-1740, 2017. https://doi.org/10.1016/j.jclepro.2016.11.116

[13] Thiel, S., Thomé-Kozmiensky, E., Winter, F., Juchelková, D. "Waste Management Volume 8", Thomé-Kozmiensky Verlag GmbH, Neuruppin, Germany, 2018.
[14] Global Water Research Coalition "Factsheet, Global Summary onPhosphorus Recovery", [pdf] Global Water Research Coalition, Unley, Australia, Available at: https://cwn-rce.ca/wp-content/ uploads/Phosphorus-Recovery-Factsheet-January-2019.pdf [Accessed: 01 March 2021]

[15] Jama-Rodzeńska, A., Białowiec, A., Koziel, J.A., Sowiński, J. "Waste to phosphorus: A transdisciplinary solution to P recovery from wastewater based on the TRIZ approach", Journal of Environmental Management, 287, Article number: 112235, 2021. https://doi.org/10.1016/j.jenvman.2021.112235

[16] Reckinger, N. "Phosphorus Extraction from Wastes: The Key to Phosphorus Problems?", Sustainable Phosphorus Alliance, [online] Available at: https://phosphorusalliance.org/2017/03/phosphorus-extraction-wastes-key-phosphorus-problems/ [Accessed: 01 April 2021]

[17] Samreen, S., Kausar, S. "Phosphorus Fertilizer: The Original and Commercial Sources", In: Zhang, T. (ed.) Phosphorus Recovery and Recycling, IntechOpen Limited, London, UK, 2019, Article number: 1507. https://doi.org/10.5772/intechopen. 82240

[18] Römer, W., Steingrobe, B. "Fertilizer Effect of Phosphorus Recycling Products", Sustainability, 10(4), Artcile number: 1166, 2018.

https://doi.org/10.3390/su10041166

[19] Reta, G., Dong, X., Li, Zh., Su, B., Hu, X., Bo, H., Yu, D., Wan, H., Liu, J., Li, Y., Xu, G., Wang, K., Xu, Sh. "Environmental impact of phosphate mining and beneficiation: review", International Journal of Hydrology, 2(4), pp. 424-431, 2018. https://doi.org/10.15406/ijh.2018.02.00106

[20] Ul-Hamid, A. "A Beginners' Guide to Scanning Electron Microscope", Springer Nature Switzerland AG, Cham, Switzerland, 2018. https://doi.org/10.1007/978-3-319-98482-7

[21] Shimadzu Scientific Instruments "BASIC Command, Reference Manual for C-R8A", Shimadzu Corporation, Tokyo, Japan, Rep. 206-94965-00, 2020.

[22] Khabas, T., Vakalova, T. "X-Ray Phase Analysis. Methodological Guidelines", Tomsk Polytechnical University, Tomsk, Russian Federation, 2017.

[23] Issayeva, A. U., Tleukeeva, A. Y. "Phosphorus-Containing Wastes of Southern Kazakhstan: Mineralogical and Microbiological Characteristics", Resources and Environment, 6(6), pp. 117-121, 2016.

https://doi.org/10.5923/j.re.20160606.03 